Agric. Biol. Chem., 42 (5), $951 \sim 956,1978$

\title{
Tissue Distribution, Developmental Changes and Some Catalytic Properties of Guanosine 3',5'-Monophosphate-dependent Protein Kinase of Bombyx mori
}

\author{
Jun Kusuda, Katsumi Koga and Katsuya HaYASHI \\ Department of Agricultural Chemistry, Faculty of Agriculture, \\ Kyushu University 46-02, Higashi-ku, Fukuoka 812, Japan
}

Received October 11, 1977

\begin{abstract}
The levels of guanosine $3^{\prime}, 5^{\prime}$-monophosphate (cGMP)-dependent protein kinase in the larval and pupal tissues of Bombyx mori were estimated. This activity was highest in the fat body of the female pupa. The enzyme showed a significant variation in activity during development of adult in female. Male silkworm gave less significant results. The cGMP-dependent kinase partially purified from the pupa could be activated by a high concentration of adenosine $3^{\prime}, 5^{\prime}$-monophosphate (cAMP) as reported for cGMP-dependent protein kinases from other sources. The nature of the enzyme thus activated and that of the enzyme activated by a low concentration of cGMP were found to be similar in several aspects. This indicates that the intrinsic activity of protein kinase from the silkworm pupa is independent of the kind of cyclic nucleotide as an activator.
\end{abstract}

Guanosine 3',5'-monophosphate (cGMP)dependent protein kinase has been found in invertebrates ${ }^{1)}$ and mammals. ${ }^{2)}$ Data about the levels of the activity among some insect and lobster tissues ${ }^{3}$ and the variation of the enzyme levels during development of Bombyx $m o r i^{4,5)}$ are available. The former half of the present study was an extension of these observations by use of Bombyx mori. The results show that cGMP-dependent enzyme exhibits specific distribution and changes in the pupa of female silkwrom. This enzyme has been purified from the pupa of this $\operatorname{strain}^{6,7)}$ and extensively characterized..$^{8 \sim 10}$ In the latter half of the present study, attempts were made to characterize further the pupal enzyme with special reference to its stimulation by cyclic nucleotides. It was found that catalytic properties of the enzyme when it was activated by a high concentration of cAMP were similar to those when activated by a low concentration of cGMP.

\section{MATERIALS AND METHODS}

Animals and materials. The silkworm (Bombyx mori) of hybrid strains was used. For the purification of enzyme, pupae were stored at $-20^{\circ} \mathrm{C}$ until use.
Protamine sulfate, crystalline bovine serum albumin and milk casein were purchased from Sigma Chem. Co.

Ammonium sulfate fractionation. In order to determine the levels of activity, 30 fresh animals were taken at appropriate stages and dissected. Each tissue, as well as the blood collected separately, was homogenized in a Teflon-glass homogenizer in 3 volumes per weight of $0.05 \mathrm{M}$ Tris- $\mathrm{HCl}$ buffer, $\mathrm{pH} 7.5$, containing $5 \mathrm{~mm}$ mercaptoethanol and $2 \mathrm{~mm}$ EDTA. Sometimes, whole bodies of animals, from which meconium was removed if necessary, were processed similarly. The homogenate was passed through double layers of gauze and the filtrate was centrifuged at $9000 \times g$ for $15 \mathrm{~min}$. To the supernatant was added solid $\mathrm{Ca}\left(\mathrm{CH}_{3} \mathrm{COO}\right)_{2}$ with stirring. During the addition $\mathrm{pH}$ was maintained at 6.8. After allowing the mixture to stand for $16 \mathrm{hr}$, the heavy precipitate containing fatty substances was centrifuged off. To the supernatant was added solid ammonium sulfate to make up 0.4 saturation at $\mathrm{pH} 7.0$. After stirring for $30 \mathrm{~min}$, the precipitate was collected by centrifugation (precipitate 1). The supernatant was brought to 0.7 saturation with solid ammonium sulfate at $\mathrm{pH}$ 7.0. After allowing the mixture to stand for $30 \mathrm{~min}$, the precipitate was collected as above (precipitate 2 ). The precipitates 1 and 2 were taken up in $0.05 \mathrm{M}$ Tris- $\mathrm{HCl}$ buffer, pH 7.5, containing $5 \mathrm{~mm}$ mercaptoethanol and $2 \mathrm{mM}$ EDTA, and dialyzed against the same solution. All the procedures were operated at $0 \sim 4^{\circ} \mathrm{C}$.

The precipitate 1 was found to be enriched with cGMP-dependent kinase and the precipitate 2 with adenosine $\quad 3^{\prime}, 5^{\prime}$-monophosphate (cAMP)-dependent 
enzyme as assayed under the standard conditions shown below (with $5 \times 10^{-7} \mathrm{M}$ CAMP or CGMP). Additional cGMP-stimulated activity was detected in the precipitate 2 and cAMP-dependent activity in the precipitate 1. These are also presented in Table I but are omitted from the data shown in Fig. 1. Each value shown below is the average of several experiments.

Standard assay conditions. The standard assay conditions were essentially the same according to Gilman. ${ }^{11)}$ The reaction mixture contained $50 \mu$ l of $50 \mathrm{~mm}$ glycerophosphate buffer, $\mathrm{pH} 7.0,1 \mathrm{mM}$ pottasium phosphate, $20 \mathrm{~mm} \mathrm{NaF}, 0.3 \mathrm{~mm}$ ethylene glycol bis ( $\beta$-aminoethylether) - $N, N^{\prime}$ - tetraacetic acid, $0.2 \mathrm{M}$ EDTA, $2 \mathrm{mM}$ theophylline, $4 \mathrm{mg} / \mathrm{ml}$ histone mixture, $0.3 \mathrm{mM} /{ }^{32} \mathrm{P}-\mathrm{ATP}, 10 \mathrm{mM} \mathrm{Mg}\left(\mathrm{CH}_{3} \mathrm{COO}\right)_{2}, 5 \times 10^{-7} \mathrm{M}$ cGMP (sometimes, the same concentration of cAMP), and enzyme, and was incubated at $30^{\circ} \mathrm{C}$ for $10 \mathrm{~min}$. Incorporation of ${ }^{32} \mathrm{P}$ was determined by the method described before. ${ }^{12)}$ One unit of activity was defined as the amount of enzyme that incorporates $1 \mathrm{pmol}$ of ${ }^{32} \mathrm{P}$ into protein per min.

Other procedures. $\quad \gamma-{ }^{32} \mathrm{P}-\mathrm{ATP}$ was prepared by the method described previously. ${ }^{13}$ Calf thymus whole histone and histone fractions were prepared according to Johns. ${ }^{14)}$ Protein was determined according to Lowry et al ${ }^{153}$ with bovine serum albumin as a standard.

Partial purification of cGMP-dependent enzyme. Pupae at day 5 after larval-pupal ecdysis $(2 \mathrm{~kg}$, a mixture of both sexes for convenience) were homogenized in a Waring blender, and the homogenate was treated with $\mathrm{Ca}\left(\mathrm{CH}_{3} \mathrm{COO}\right)_{2}$ and then fractionated by ammonium sulfate as described above. In this purification experiment only the precipitate of 0 to 0.4 saturation was collected. Detajls for the further purification procedures were published elsewhere. ${ }^{183}$ Briefly, the precipitate was dissolved in an appropriate buffer, dialyzed, and then made up to $\mathrm{pH} 4.8$. The precipitate formed was removed and the supernatant was again fractionated by ammonium sulfate. The precipitate of 0.25 to 0.35 saturation was collected. After dialysis the sample was subjected to DEAEcellulose column chromatography and 2 cycles of Sephadex G-200 gel filtration. The filtrate was concentrated in a collodion bag. By these procedures the enzyme was purified 105 -fold with a recovery of $24 \%$. The final preparation gave several protein bands upon polyacrylamide gel electrophoresis, indicating that the enzyme was still not pure. However, the specific activity of the enzyme preparation decreased as the purification processes such as hydroxylapatite and P-cellulose chromatographies proceeded; therefore further purification was not made.

\section{RESULTS}

\section{Relative levels in tissues and developmental} changes of activity

The levels of cGMP-dependent protein kinase were determined together with those of cAMP-dependent enzyme. In order to distinguish both activities, it was desired to separate the two enzymes before assay. The separation of the two enzymes could be achieved substantially by simple ammonium sulfate fractionation as described in METHODs. This procedure was more facile than gel treatment or chromatography with hydroxylapatite previously applied for the same purpose,,$^{3 \sim 51}$ and the degrees of separation of the two classes of kinases (see below) were comparable to, or sometimes better than those given by the latter procedures ( $c f$. figures or tables in refs. $3 \sim 5$ ). Table I shows the levels of protein kinases expressed in terms of relative activities to the soluble protein concentrations of individual samples. In the larval silk gland, and the pupal testes and ovaries, fractionation of the two activities was unsuccessful. Nevertheless, in the larval and pupal fat bodies, the whole bodies of puape and some other tissues, contamination of cAMP-dependent kinase in the precipitate 1 seemed to be very small. Because cAMP-stimulated kinase activity was relatively lower than cGMP-stimulated kinase activity. The ratios calculated by the formula $[(+\mathrm{cAMP}-\mathrm{Basal}) /(+\mathrm{cGMP}$ - Basal $) \times 100]$ were up to $16 \%$; this value was comparable to that of the partially purified, "cAMP-dependent kinase-free" preparation of the present enzyme (see below and Discussion). Thus, we may conclude that the level of cGMP-dependent protein kinase was the highest in the pupal fat body, especially in the female fat body.

Contamination of cGMP enzyme in the precipitate 2 from the larval tissues (except the blood) seemed also to be very small as deduced from the relatively low dependencies on cGMP. However, the precipitate 2 from the pupal organs (and the whole bodies of pupae) exhibited significant levels of cGMP-stimulated 
TABle I. Levels of cGMP-dependent AND cAMP-DEPendent Protein KINASE ACTIVITIES IN TISSUES of Bombyx mori

\begin{tabular}{|c|c|c|c|c|c|c|}
\hline \multirow{3}{*}{ Stage, sex, $\&$ tissue } & \multicolumn{6}{|c|}{ Activity of } \\
\hline & \multicolumn{3}{|c|}{ Precipitate $1^{a}$} & \multicolumn{3}{|c|}{ Precipitate $2^{a}$} \\
\hline & \multicolumn{6}{|c|}{ (Units/mg protein) } \\
\hline \multicolumn{7}{|l|}{ Larva $^{b}$ (male + female) } \\
\hline Blood & 14.8 & 21.4 & 61.0 & 11.7 & 21.0 & 22.0 \\
\hline Mid gut & 0.2 & 0 & 0.2 & 0 & 0.4 & 0 \\
\hline Fat body & 33.8 & 31.8 & 81.0 & 0 & 83.9 & 14.3 \\
\hline Silk glands & 1.9 & 11.9 & 5.4 & 1.1 & 15.4 & 1.8 \\
\hline Integument + muscle & 2.3 & 4.3 & 5.0 & 0.9 & 26.7 & 3.7 \\
\hline \multicolumn{7}{|l|}{$\mathrm{Pupa}^{\circ}$ (male) } \\
\hline Mid gut & 11.6 & 10.3 & 44.7 & 6.0 & 20.3 & 27.0 \\
\hline Fat body & 36.1 & 43.5 & 84.4 & 29.3 & 36.7 & 28.7 \\
\hline Testes & 59.0 & 52.9 & 71.2 & 13.0 & 51.0 & 51.0 \\
\hline Integument + muscle & 14.3 & 31.5 & 35.5 & 18.2 & 58.4 & 42.9 \\
\hline \multicolumn{7}{|l|}{ Pupa $^{c}$ (female) } \\
\hline Mid gut & 12.7 & 19.3 & 45.8 & 5.0 & 22.0 & 12.0 \\
\hline Fat body & 82.0 & 122.4 & 390.0 & 67.5 & 97.1 & 86.0 \\
\hline Ovaries & 3.4 & 9.9 & 11.7 & 4.6 & 5.9 & 5.6 \\
\hline Integument + muscle & 22.7 & 24.7 & 46.4 & 31.5 & 48.5 & 42.0 \\
\hline \multicolumn{7}{|l|}{ Pupa $^{\circ}$ (male + female) } \\
\hline Whole body - meconium & 16.0 & 19.3 & 40.7 & 16.2 & 28.2 & 21.4 \\
\hline $\begin{array}{l}\text { a Ammonium sulfate precipita } \\
\text { MeTHods). }\end{array}$ & rich & GMP. & cAMP & dent & ties, $\mathrm{r}$ & ively \\
\hline $\begin{array}{l}b \quad \text { At day } 3 \text { of the } 5 \text { th instar. } \\
\text { At day } 8 \sim 9 \text { after larval-pupal }\end{array}$ & & & & & & \\
\hline
\end{tabular}

activity. These results would explain by assuming that the pupae contain a very small amount of cAMP-dependent enzyme compared to cGMP-dependent kinase, but the larvae possess both at comparable levels.

As for the larval fat body, separation of the two kinases seemed to be satisfactory. This would indicate that both kinases are rich in that organ. This result conflicts with previous observations in which the larval fat bodies of the silkmoth $^{3)}$ and silkworm ${ }^{4}$ exhibited very small or no activity of cAMP-dependent kinase while the tissue had high units of cGMPdependent activity. The reason for this discrepancy is unknown but it may partly be ascribed to the different method for preseparation of the enzymes.

The cGMP-dependent and cAMP-dependent activities in whole bodies were estimated during pupal-adult development. As shown in Fig. 1, cGMP-stimulated kinase reached a maximum at day 5 after larval-pupal ecdysis in female. The cAMP-dependent activity in female and both activities in male exhibited less significant patterns.

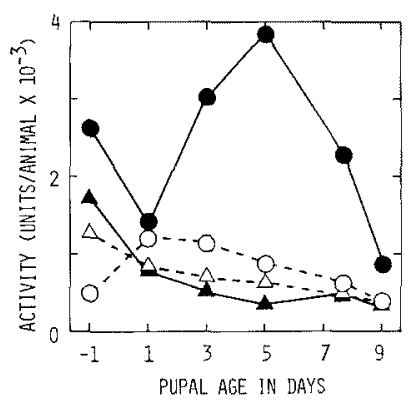

Frg. 1. Changes in Activities of cGMP-dependent and cAMP-dependent Protein Kinase Activities during Pupal Age.

Ammonium sulfate fractions of whole body extracts were used for assay (see METHODs). Basal activities were deducted. and $\bigcirc$, with cGMP (precipitate 1); $\Delta$ and $\triangle$, with CAMP (precipitate 2 ). Closed symbols, female; open symbols, male. Larval-pupal ecdysis occurred at day 0 , and emergence at day 11 . 
On the whole, the most significant feature was brought about by cGMP-dependent protein kinase. Therefore, attempts were made to purify and characterize the enzyme.

\section{Dependency to cyclic nucleotides}

The enzyme was partially purified as described in Merhods. The final preparation showed differential stimulatory responses to cGMP and cAMP; the response pattern was essentially superimposable to that previously obtained for the same enzyme from the same source, ${ }^{7}$ and was omitted in the present communication. The apparent $K_{a}$ value (the concentration needed for half-maximal activation as defined before ${ }^{7}$ ) for cGMP was $3 \times 10^{-8} \mathrm{M}$, while that for cAMP was $5 \times 10^{-7} \mathrm{M}$. The kinase was completely activated by $1 \times 10^{-7} \mathrm{M}$ cGMP or by $1 \times 10^{-5} \mathrm{M}$ cAMP. Under the standard assay conditions $\left(5 \times 10^{-7} \mathrm{M}\right.$ either of cyclic nucleotides), the enzyme preparation showed a relative dependency on cAMP at $15 \%$ compared to cGMP (for calculation, see above). These values were essentially in agreement with those reported previously. ${ }^{\text {? }}$

Spontaneous loss of the nucleotide dependency was sometimes observed during purification of the present enzyme, especially after gel filtration. However, the dependency was restored in concentrated enzyme solution. This phenomenon may possibly be related to some modulator system similar to that reported for mammalian cGMP-dependent protein kinase, ${ }^{17}$ ) although the presence of this system in insect kinase has not been demonstrated.

Properties of the enzyme when activated by CAMP and $C G M P$

In insect, the content of cGMP and that of cAMP were found to be comparable to each other, although their ratio depended on the tissue (e.g. ref. 18). It is interesting whether these nucleotides differ qualitatively with respect to their ability to activate protein kinase. Thus, the properties of the partially purified enzyme when maximally activated by cAMP were compared to those of the same

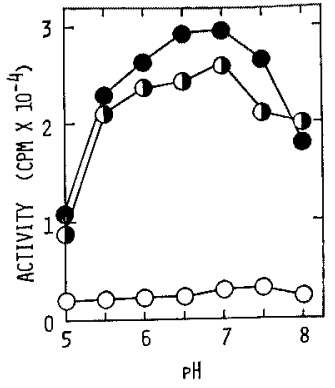

FIG. 2. Effect of $\mathrm{pH}$ on Activity of Partially Purified cGMP-dependent Protein Kinase as Activated by $10 \mu \mathrm{M}$ cAMP (\$) or by $0.5 \mu \mathrm{M}$ cGMP ( $(\bullet)$. $\quad$, without cyclic nucleotide. Other conditions were as described in METHODs except that $\mathrm{pH}$ was varied.

Table II. Specificity for Protein Substrate of Partially Purified cGMP-dependent Protein Kinase

Assay was made with $10 \mu \mathrm{M}$ cAMP or with $0.5 \mu \mathrm{M}$ cGMP. Other conditions were as described in METHODs except that protein substrate was varied.

\begin{tabular}{llrr}
\hline \multirow{3}{*}{ Substrate } & \multicolumn{3}{c}{ Activity } \\
\cline { 2 - 4 } & Basal & $\begin{array}{c}\text { +cAMP } \\
\text { (Units) }\end{array}$ & +cGMP \\
\hline Histone & 6.1 & 26.8 & 36.6 \\
Mixture & 0 & 0.8 & 0.7 \\
H1 & 0 & 4.6 & 5.2 \\
H2A & 1.2 & 33.8 & 44.4 \\
H2B & 0 & 3.6 & 5.5 \\
H3 & 0 & 10.1 & 13.4 \\
Casein & 0 & 0.1 & 0.7 \\
Protamine & 0.2 & 1.1 & 1.0 \\
Albumin & & &
\end{tabular}

enzyme when activated by cGMP. The results show that the properties were similar in optimum $\mathrm{pH}$ (Fig. 2), specificity to protein substrate (Table II), and response to several heavy metal ions such as $\mathrm{Ca}^{2+}, \mathrm{Mn}^{2+}, \mathrm{Co}^{2+}$, $\mathrm{Zn}^{2+}, \mathrm{Ba}^{2+}$, and $\mathrm{Pb}^{2+}$ substituted for $\mathrm{Mg}^{2+}$ under the standard assay conditions (data not shown). A similar finding has been shown in a previous report in which a mammalian cGMPdependent protein kinase gave the same response curve versus changing levels of $\mathrm{Mg}^{2+}$ whether it was activated by cGMP or by cAMP. ${ }^{19 \text {; }}$

The reaction rate of the partially purified enzyme was measured at various concentrations of ATP. The Lineweaver-Burk plots 


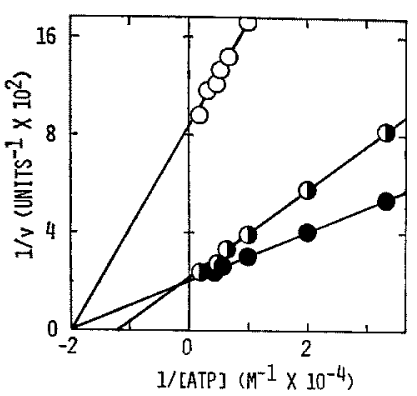

FIG. 3. Effect of ATP Concentration on Activity of Partially Purified cGMP-dependent Protein Kinase as Activated by $10 \mu \mathrm{M}$ cAMP (o) or by $0.5 \mu \mathrm{M}$ cGMP (๑). $O$, without cyclic nucleotide. Other conditions were as described in METHoDs except that the ATP level was varied.

(Fig. 3) showed that the $K m$ values for ATP when activated by cGMP and cAMP were $5.0 \times 10^{-5} \mathrm{M}$ and $8.4 \times 10^{-5}$, respectively. Similar experiments were made with histone mixture (figure not shown) and the $\mathrm{Km}$ values for this substrate were $0.69 \mathrm{mg} / \mathrm{ml}$ and $1.43 \mathrm{mg} / \mathrm{ml}$ in the same order as above. In contrast to the definite but small difference in $K m$, the $V_{\max }$ data for ATP and histone did not depend substantially upon the cyclic nucleotide used (see Fig. 3 for ATP).

As reported in mammalian cAMP-dependent protein kinase, ${ }^{20)}$ the present enzyme was inhibited by adenine derivatives, and this inhibition was suppressed by a higher concentration of ATP. The order of the adenine compounds in degree of inhibition was ADP $>$ adenosine $>$ adenine $>$ AMP. The enzyme showed also high sensitivity to deoxyadenosine, but low sensitivity to guanine and cytosine derivatives. The same results were obtained for the enzyme preparations stimulated by cAMP or cGMP. Details for the experiments were previously published elsewhere. ${ }^{16\}}$

\section{DISCUSSION}

The finding that the cGMP-dependent protein kinase distributed in specific tissues and the amount of the enzyme was different in developmental stages in Bombyx mori suggests that the cellular system related to cGMP may play a role in specialized functions rather than in fundamental, housekeeping metabolism. A similar inference has previously been drawn. ${ }^{3)}$ Nevertheless, the present study has shown that cGMP differ from cAMP mainly in "qualitative" aspects in the activation of protein kinase. $K m$ 's of the enzyme for ATP and histone depend to some extent upon the cyclic nucleotide used. This could, however, be explained by assuming that cAMP (but not cGMP) interferes with the activity of the enzyme. In fact, adenine derivatives showed high inhibitory potency but guanine derivatives did not (see above). It is likely that cAMP, at the concentration required for the full activation of cGMP-dependent kinase, competes with ATP, as is also deduced from the feature of kinetics (Fig. 3). Moreover, results from the cGMP-dependent protein kinase of the silkworm egg have shown that Km's for ATP and histone under the presence of an unsaturated amount of cAMP are the same as those when the enzyme is activated by cGMP. ${ }^{21}$,

It should be mentioned here that the present enzyme was not completely purified and the possibility of contamination of cAMP-dependent enzyme could not be ruled out. However, the ammonium sulfate fractionation method applied to the whole body samples of pupa consistently gave substantial separation of the latter enzyme from the crude extracts (a typical result is seen in the lowest line of Table I); thus the contamination of the latter enzyme in the final preparation may be little if any (ammonium sulfate fractionation was repeated in a more defined way during purification). Moreover, the present enzyme showed a cyclic nucleotide-dependency similar to cGMP-dependent enzymes obtained previously which were expected to be practically free from contaminating cAMP-dependent kinase. ${ }^{6,7,19)}$ The final enzyme preparation showed several electrophoretic bands, but the precise nature of the components are unknown. We have not studied about the synergistic effect of, or competition between cAMP and cGMP.

Within these limitations, our results and dis- 
cussions described above would indicate that the intrinsic activity of cGMP-dependent protein kinase partially purified from the silkworm pupa is independent of the kind of cyclic nucleotide as a regulator. This is of interest since there is evidence that this enzyme does not separate the cyclic nucleotidebinding site from the catalytic site, as general cAMP-dependent kinases do, ${ }^{7,8)}$ although precise mechanism of regulatory process of the present enzyme remains to be elucidated.

Acknowledgement. The authors express their thanks to Dr. H. Doira, Mr. H. Kihara, Mr. Y. Torihama, Mr. T. Hashiguchi, and Mr. M. Nagashima for their generous supply of silkworms, and to $\mathrm{Mr}$. M. Ikeda and Mr. S. Shibata for their assistance.

\section{REFERENCES}

1) J. F. Kuo and P. Greengard, J. Biol. Chem., 245, $2493(1970)$.

2) J. F. Kuo, Proc. Natl. Acad. Sci. U.S.A., 71, 4037 (1974).

3) J.F. Kuo, G. R. Wyatt and P. Greengard, J. Biol. Chem., 246, 7159 (1970).

4) S. Y. Takahashi, Insect Biochem., 6, 519 (1976).

5) S. Y. Takahashi, T. Ohoka, K. Hanaoka, T. Kageyama and E. Ohnishi, Dev. Growth Differ., 17, 227 (1975).

6) K. Nishiyama, H. Katakami, H. Yamamura, Y. Takai, R. Shimomura and Y. Nishizuka, J. Biol. Chem, 250, 1297 (1975).
7) Y. Takai, S. Nakaya, M. Inoue, A. Kishimoto, K. Nishiyama, H. Yamamura and Y. Nishizuka, J. Biol. Chem., 251, 1481 (1976).

8) M. Inoue, A. Kishimoto, Y. Takai and $Y$. Nishizuka, ibid., 251, 4476 (1976).

9) M. Yamamoto, Y. Takai, E. Hashimoto and Y. Nishizuka, J. Biochem., 81, 1857 (1977).

10) M. Chihara-Nakashima, E. Hashimoto and $Y$. Nishizuka, ibid., 81, 1863 (1977).

11) A. G. Gilman, Proc. Natl. Acad. Sci. U.S.A., 67, 305 (1970).

12) F. J. Bollum, "Methods in Enzymology," Vol. 12B, ed. by L. Grossman and K. Moldave, Academic Press Inc., New York, N. Y., 1968, p. 169.

13) I. M. Glynn and J. B. Chappel, Biochem. J., 90, 147 (1964).

14) E. W. Johns, ibid., 104, 78 (1967).

15) O. H. Lowry, N. J. Rosebrough, A. L. Farr and R. J. Randall, J. Biol. Chem., 193, 265 (1951).

16) J. Kusuda, K. Koga and K. Hayashi, Sci. Bull. Fac. Agric., Kyushu Univ., 30, 179 (1976).

17) T. E. Donnelly, Jr., J. F. Kuo, P. L. Reyes, Y. P. Liu and P. Greengard, J. Biol. Chem., 248, 190 (1973).

18) J. F. Kuo, T. P. Lee, P. L. Reyes, K. G. Walton, T. E. Donnelly, Jr. and P. Greengard, ibid., 247, 16 (1972).

19) Y. Takai, K. Nishiyama, H. Yamamura and $Y$. Nishizuka, ibid., 250, 4690 (1975).

20) H. Iwai, M. Inamasu and S. Takeyama, Biochem. Biophys. Res. Commun., 46, 824 (1972).

21) S. Y. Takahashi, T. Kageyama, T. Ohoka and E. Ohnishi, Insect Biochem., 4, 429 (1974). 